\title{
Synthesis of 4H-3,1-benzoxazin-4-one 2-phenyl Using Cyanuric Chloride as a Cyclization Agent
}

\author{
Sohrab Abdollahi* and Mehdi Shariat \\ Department of Chemistry \\ Payamnoor University of Golpayegan, \\ Golpayegan Iran \\ e-mail: sohrab202020@yahoo.com
}

Received: 15 July 2005 / Accepted: 24 October 2004 / Published: 12 December 2005

\section{Keywords:}<smiles>Nc1ccccc1C(=O)O</smiles>

1<smiles>O=C(Nc1ccccc1C(=O)O)c1ccccc1</smiles>

3<smiles>O=C(Cl)c1ccccc1</smiles>

2<smiles>Clc1nc(Cl)nc(Cl)n1</smiles>

$\frac{\text { triethyamine }}{\text { chloroform }}$<smiles>O=C(Nc1ccccc1C(=O)O)c1ccccc1</smiles><smiles>O=c1oc(-c2ccccc2)nc2ccccc12</smiles>

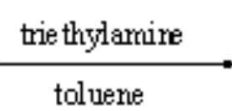

5

The preparation of different derivatives of benzoxazinone can be considered important because they have different kinds of pharmaceutical, agricultural and industrial applications [1-4]. The synthesis of benzoxazinone derivative, 4H-3,1-benzoxazin-4-one 2-(N-phthaloylmethyl), was reported previously by our team [5]. In this paper we have used the same method to synthesize 4H-3,1-benzoxazin-4-one 2-phenyl 5. This synthesis occurs in two steps: In the first step, anthranilic acid 1 (4.11g) in $40 \mathrm{ml}$ chloroform was mixed with $4.15 \mathrm{ml}$ anhydrous triethylamine and $3.48 \mathrm{ml}$ benzoyl chloride 2 in $10 \mathrm{ml}$ chloroform. In the second step, the resulting benzamid 3 (2.41 g) mixed with $100 \mathrm{ml}$ anhydrous toluene, $1.52 \mathrm{ml}$ triethylamine and $1.84 \mathrm{~g}$ cyanuric chloride 4 is refluxed for one week. After purification, drying with magnesium sulfate, the resulting benzoxazinone $\mathbf{5}$ as a final product is recrystallized in $30 \%$ etherchloroform solution. Yield $67.8 \%$ (63\% overall)

For the compound 3:

${ }^{1} \mathrm{H}-\mathrm{NMR}\left(\mathrm{CDCl}_{3}\right): \delta=7.10-9.13(\mathrm{~m}, 9 \mathrm{H}, \mathrm{Ar}-\mathrm{H} ; \mathrm{NH}) ; 12.1-12.3$ (broad singlet,-COOH).

IR $\left(\mathrm{KBr}, \mathrm{cm}^{-1}\right): 2460-3115 ; 1680 ; 1639$.

For the product 5

Melting point: $122-124^{\circ} \mathrm{C}$ (lit. 123-125) [6].

${ }^{1} \mathrm{H}-\mathrm{NMR}\left(\mathrm{CDCl}_{3}\right): \delta=7.25-8.73(\mathrm{~m}, 9 \mathrm{H}, \mathrm{Ar}-\mathrm{H})$. 
IR $\left(\mathrm{KBr}, \mathrm{cm}^{-1}\right): 1760 ; 1608$.

Elemental Analysis: Calculated for $\mathrm{C}_{14} \mathrm{H}_{9} \mathrm{NO}_{2}$ (223.23): C, 75.33\%; H, 4.06\%; N, 6.27\%; O, 14.33 .

Found: C, 75.01\%; H, 4.26\%; N, 6.3\%; O, 14.43\%.

\section{Acknowledgement}

The authors are grateful for the support and financial help that were received by the University of Payamnoor.

\section{References}

1. Bulluci, C.; Gualtieri, F.; Chiarini, A. Eur. J. Med. Chem. 1987, 22, 473.

2. Wiker, P.; Wilson, A. J. Am. Chem. Soc. 1955, 77, 5598.

3. Bouillant, M. L.; Farre-Bonvin, J.; Ricci, P. Tetrahedron Letters, 1983, $24,51$.

4. Donchet, M.; Martin-Tuguy, J.; Marais, A.; Pupet, A. Phytochem, 1981, 23, 1901.

5. Shariat, M.; Abdollahi, S. Molecules, 2004, 9, 705-712.

6. Bain, D. I.; Smalley, R. K. J. Chem. Soc., C 1968, 13, 1593-7.

Sample Availability: Available from the authors.

(C) 2005 MDPI. All rights reserved. 
Received: 8 March 2004 / Accepted: 18 March 2004 / Published: 1 August 2005

Sample Availability: Available from MDPI.

(C) 2005 MDPI. All rights reserved. 